Research/Technical Note

\title{
Bio-Restoration of Mural Paintings Using Viable Cells of Pseudomonas stutzeri and Characterization of These Murals
}

\author{
Abeer Fouad ElHagrassy \\ Conservation Department, Faculty of Archaeology, Fayoum University, Fayoum, Egypt \\ Email address: \\ afa01@fayoum.edu.eg
}

To cite this article:

Abeer Fouad ElHagrassy. Bio-Restoration of Mural Paintings Using Viable Cells of Pseudomonas stutzeri and Characterization of These Murals. International Journal of Archaeology. Vol. 7, No. 1, 2019, pp. 8-16. doi: 10.11648/j.ija.20190701.12

Received: May 15, 2019; Accepted: June 12, 2019; Published: July 13, 2019

\begin{abstract}
In the 19th-century Egypt had a strong earthquake leads to damage of several mural paintings. Mural paintings in Ali kadkhoda house (El Rabiemaya), in Cairo, Egypt were among the affected. According to these damages the mural paintings were pre-consolidated and covered by medical gauze and animal glue as an adhesive under extremely dangerous conditions. The traditional conservation methodology as hot water, and acrylics that carried on these mural paintings to strip the medical gauze and animal glue showed no positive results and caused removal of the pigments. Viable bacterial cells of Pseudomonas stutzeri, were used with Broth- animal glue media mixed with agar as a delivery system (gel material) to remove the polymerized animal glue only in 3 hours at $35^{\circ} \mathrm{C}$. The effectiveness of the bio-cleaning test was assessed. The results confirmed the success of this cleaning biotechnology to remove the animal glue as an organic matter without side effects on the mural paintings pigments. The Bio-restoration technique was safe, low-cost, non-invasive, time saving, and risk-free. Silver nano particles were used to sterilization the mural paintings after final step in the bio-restoration process to insure the death of bacterial cells. At the end, the mural paintings were characterized using SEM-EDX, FTIR, and XRD.
\end{abstract}

Keywords: Bio-Cleaning, Bio-restoration, Viable Cells, Pseudomonas stutzeri, Mural Paintings, Egypt

\section{Introduction}

Monuments and Mural paintings in Egypt, after the earthquake in 1992, were damaged by the strong vibrations, theorize impendence for losing these mural paintings. Figure 1. A committee for protecting the cultural heritage stored all these damage mural with medical gauze and animal glue as an adhesive to prevent any further damage Figure. 2. Some of these mural paintings are left until now without any conservation treatments.

Ali katkhoda house is one of these buildings that its murals were treated by this technique and kept from 1992-2014. This house (known as El Rabiemaya) is located in Darb Al-Hajar Street. The house contains two holes one is larger than the other. All the walls in the second floor are decorated with several mural paintings with different fields. [1].

Several methods were carried out on these murals to strip the medical gauze and animal glue but due to the long period the animal glue had polymerized and any attempts to take it off showed no positive results and caused removal of the pigments as well.

Moreover, organic compounds (such as animal glue and casein) were used as consolidating materials beside the varnish layer applied in $18^{\text {th }}$ and $19^{\text {th }}$ century on the painted surface which lead to darkened pigments and bio pigmentation. [2].

The use of bio-restoration process, thus, the only way to solve these two problems and to let the noble mural paintings easy to be characterized. Microorganisms were deemed responsible for the changing in monuments and mural paintings [3-5], but on the other hand they have decisive effects in conservation and restoration process [6-10]. Bacteria has cleaning advantages over other treatments methodology such as laser, especially when the deteriorated 
substances need to be removed are complex [11] never less, Bacteria were able to acclimate themselves to different environmental parameter ( $\mathrm{pH}$, temperature, and nutrients).

Cleaning organic matter deteriorated mural paintings by using Pseudomonas stutzeri had several ways of application such as the immersion of portable monuments in a solution with bacteria's cell or using different delivery systems like cotton, Sepiolite, Carbogel,, and Hydrobiogel-97. [6, 11-16].

In this study the bio-restoration technique was proceeded by direct application of viable bacterial cells of $P$. stutzeri, and agar as a delivery system on the surface of the covered mural paintings. The bacterial cells removed a most of animal glue in only 10 hours and the gauze became easy to be removed without causing damage to pigments. After removal of gauze, the mural paintings were characterized by XRD, SEM-EDX, and FTIR.

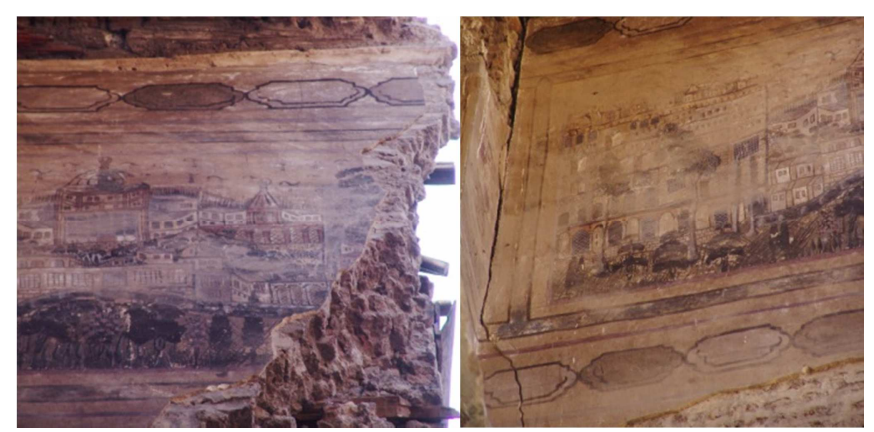

Figure 1. The mural painting of Ali Katkhoda house after the Earthquake in 1992.

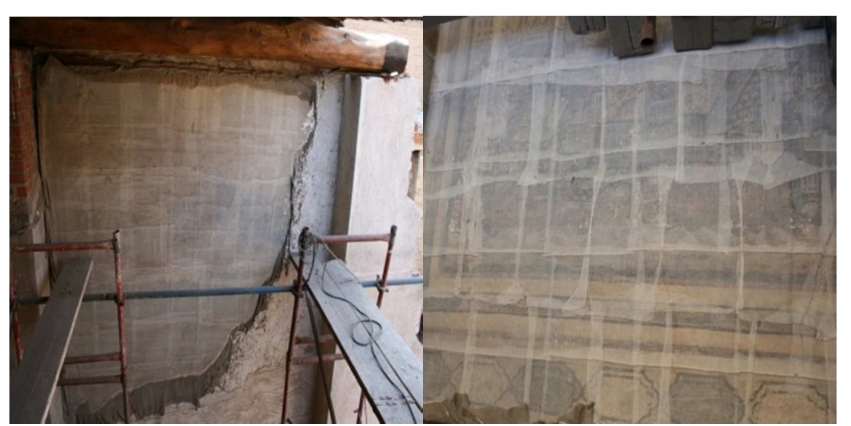

Figure 2. The same mural paintings after restored by medical gauze and animal glue.

After final bio cleaning, silver nano particles were used as an antimicrobial agents, Ag nano particle is one of the essential antimicrobial Nano particles, which is used in cultural heritage [17] and for sterilization of mural paintings without causing damage result or colour effect on mural paintings. [18]

\section{Material and Methods}

\subsection{Bacterium Cells and Culture Media}

Viable cells of Pseudomonas stutzeri ATCC 17589 strain (American Type Culture Collection, Rockville, MD, USA) were used for the cleaning process.

\subsection{Growth Media}

Two different media were used to cultivate Pseudomonas stutzeri cells MI - Broth media (Z699187- Sigma Aldrich) and Broth- animal glue-containing agar media that consist of $0.5 \mathrm{~g}$ $\mathrm{I}^{-1} \mathrm{KH}_{2} \mathrm{PO}_{4}, 0.5 \mathrm{~g} \mathrm{l}^{-1} \mathrm{MgSO}_{4} \cdot 7 \mathrm{H}_{2} \mathrm{O}, 4 \mathrm{~g} \mathrm{l}^{-1}$ animal glue, and 15 $\mathrm{g}^{-1}$ of agar in distilled $\mathrm{H}_{2} \mathrm{O}$. (Jeszeová1 et al, 2018). Autoclave used for sterilizing the media at $110^{\circ} \mathrm{C}$ for 45 minutes and incubating in a shaker $\left(300 \mathrm{rev}\right.$ min at $30^{\circ} \mathrm{C}$ for 48h).

\subsection{Cultural Methods}

Suspensions with about $1 \times 10^{10}$ colony forming unit (CFU) per $1 \mathrm{ml}$, obtained by inoculating $10 \mathrm{ml}$ of a nightly broth-culture and broth-animal glue culture into $1 \mathrm{~L}$ of fresh broth medium, and incubating it in a shaker $(300 \mathrm{rpm})$ for $24 \mathrm{~h}$ at $30^{\circ} \mathrm{C}$. The bacterial cells were washed by phosphate-buffered saline two times, and then were re-suspended in sterile water, $\mathrm{pH}$ 6.9; the final cells concentration was above $1 \times 10^{10}$ concentrations cells $\mathrm{ml}^{-1}$, the cells were used immediately or stored at $4^{\circ} \mathrm{C}$ during conservation.

\subsection{Total Adenosine Triphosphate Determination}

Total Adenosine triphosphate (ATP) inspect to monitor the growth culture on the scale's laboratory, and the viability of the Pseudomonas stutzeri cells hang during the in situ bio-cleaning processes, were used a specific enzymatic kit (MAK, Acetyl choline esterase, activity assay-kit-sufficient for clorometric tests, Netherlands). A Bio-counter luminometer $\left(\begin{array}{ll}1500 & \mathrm{P}) \\ \text { connected with a (PMT) }\end{array}\right.$ photomultiplier tube.

\subsection{Preparing Replica and Artificial Aging}

In order to evaluate the effectiveness of the bio-cleaning process, artificial altered specimens, simulating the presence of animal glue were prepared and applied by soft manual brush as a thin layer directly on the upper surface of gauze on replica (size: $25^{*} 25^{*} 5 \mathrm{~cm}$ ) of the of mural paintings. Once the animal glue formed a thin film, about 10 cycles of thermal aging cycles were carried out as 8 hours in an oven at $60^{\circ} \mathrm{c}$ followed by 8 hours in room temperature. Figure 3 .

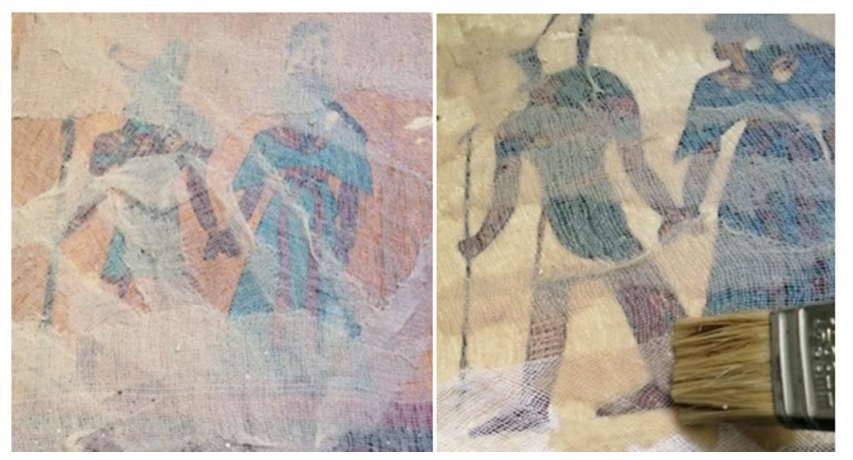

Figure 3. The two replica during application the animal glue.

Two aged replica were used in the experiment: the first 
replica was covered by the Pseudomonas stutzeri which was distributed over the surface and covered by hydrophilic cotton layer and left for different period $(30,60,90,120,180$ minutes).

The second application was agar delivery system, Agar was mixed with the media and then applied over the aged replica (0.5 cm high) for (30, 60, 90, 120, 180 minutes).

\subsection{Bio-cleaning Application on Mural Paintings}

Pseudomonas stutzeri cells with broth animal glue were applied on the aged replica with two carriers (cotton, and agar) for different period $(60,120$ and $180 \mathrm{~min})$ at $\left(35^{\circ} \mathrm{C}\right)$ and $50 \%$ relative humidity, using a controlled room chamber. At the end of each treatment, the application supports were removed and the treated areas were carefully washed with a sponge impregnate with sterile distilled water.

\subsection{Silver Nano Particles}

Nano silver particles (30nm) made by (EGNC- Egypt). 0.1g of $\mathrm{AgNO}_{3}$ adds to $50 \mathrm{ml}$ of distil water and stir for $30 \mathrm{~min}$ at $80^{\circ} \mathrm{C}$. $0.1 \mathrm{M}$ Tri-sodium citrate was added in ultrasonic processors for stationary operation (Hielscher Company, German model UP 200) until the light brown colour appeared.

\subsection{X-ray Diffraction}

XRD Bruker company model D8 used for compounds identification of Mural paintings. It include a reflectometry, features a high-resolution diffraction, in-plane grazing incidence diffraction (IP-GID), in addition to small angle $\mathrm{X}$-ray scattering (SAXS).

\subsection{FTIR Spectroscopy}

Nicolet Magna 75 FTIR spectrometer used for Absorption spectra in the IR region. 32 signal scans obtained on the real fragments of the mural paintings. Only a milligrams of samples mingled in $\mathrm{KBr}$ (IR grade, Merck) bead with a diameter of $13 \mathrm{~mm}$ approximately.

\subsection{SEM- EDX}

A Jeol (Tokyo, Japan) JSM 5600 LV SEM images were used for examinations. It was equipped with EDX microanalysis detector (an Oxford Instruments 6587). Low vacuum conditions was the perfect conditions for images due to the non-effected changing of the samples.

\section{Result}

\subsection{FTIR Analyses}

The analyses by FTIR techniques indicated the presence of substances identifying the animal glue as protein substance, used for covering the mural paintings in the past over the gauze. The sharp peak at $3300-3430 \mathrm{~cm}^{-1}$ is the N-H stretching of $\mathrm{CONH}_{2}$ in protein. At $1640 \mathrm{~cm}^{-1}$ a special characteristic peaks of the secondary amide protein $(\mathrm{C}=\mathrm{O})$. At $1163 \mathrm{~cm}^{-1}$ a methylene ether group (C-O-C) was indicated. Figure 4.

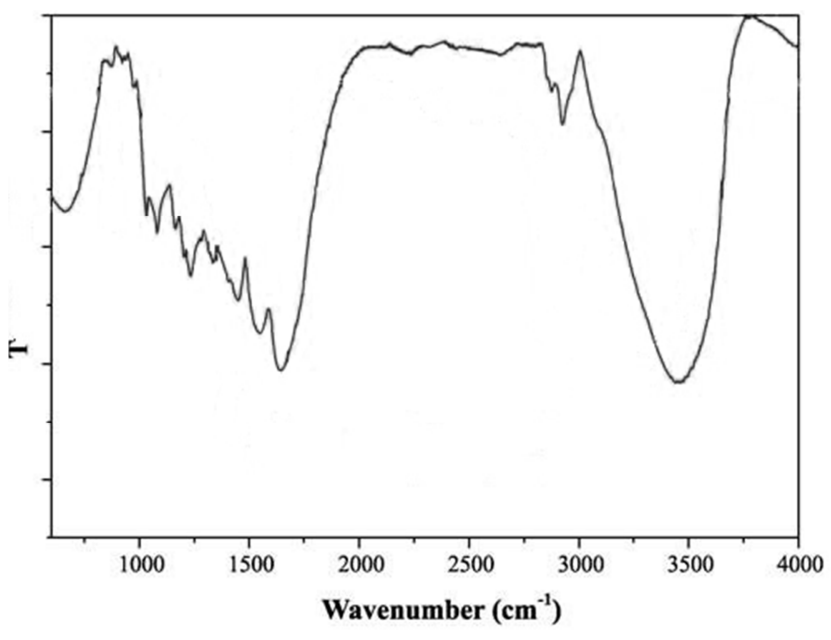

Figure 4. FTIR spectrum of the animal glue.

\subsection{Viable Cell Counts and ATP Determination}

P. stutzeri growth rate at $30^{\circ} \mathrm{C}$ on broth containing animal glue and broth medium, it showed the highest cell density (1.6 O. D. ${ }_{550}$ and $>10.3 \log \mathrm{CFU} \mathrm{ml}{ }^{-1}$ ) on the broth - animal glue medium than broth medium (1.23 O. D.550 and $>8.5 \log$ CFU $\left.\mathrm{ml}^{-1}\right)$.

ATP content according to relative luminose unit showed that using broth - animal agar medium was higher than broth medium (21 $000 \mathrm{pg} \mathrm{ml}^{-1}$ and $18000 \mathrm{pg} \mathrm{ml}^{-1}$, respectively).

The effectiveness of temperature on the growth of the Pseudomonas stutzeri both on Broth media and broth- animal glue media was assessed by O. D. 560 and CFU for $36 \mathrm{~h}$ at 10,15 , $20,25,30,35,40^{\circ} \mathrm{C}$.

Cell density increased ascendant by increasing temperatures and was a very marked increase in cell growth at $35^{\circ} \mathrm{C}$ at $36 \mathrm{~h}$. Figure 5.

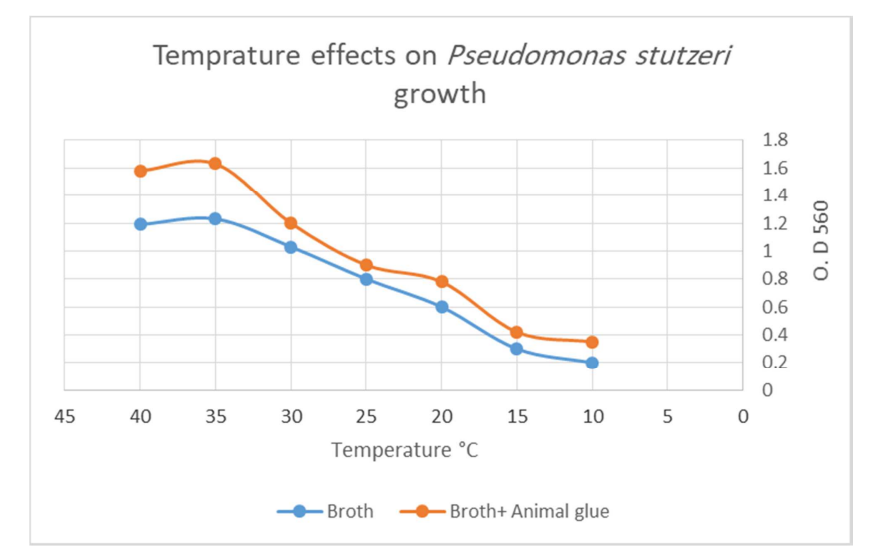

Figure 5. Effect of temperature on the Pseudomonas stutzeri on different growth media.

The effectiveness of $\mathrm{pH}$ value on the growth of the Pseudomonas stutzeri both on broth media and broth- animal glue media was assessed by O. D. 560 and CFU at 5.5, 6, 6.5, 7, 7.5, 8 and 8.5.

A significant increase in the cell growth density was observed at $\mathrm{pH}=7.5$. Figure 6 . 
$\mathrm{pH}$ effects on Pseudomonas stutzeri growth

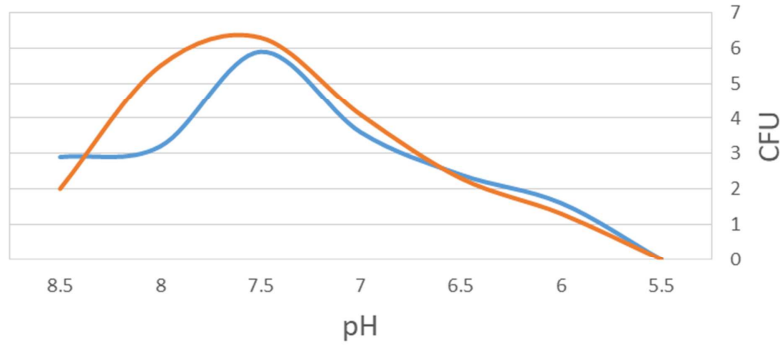

— broth media $\quad$ broth animal glue media

Figure 6. Effect of $\mathrm{pH}$ on the growth rate of the Pseudomonas stutzeri.

\subsection{Application of Bio-restoration Process on the Replica}

The two aged replica were used in the experiment (see 2.2) for different periods $(30,60,90,120,180$ minutes). As seen in Table 1. Figure 7.
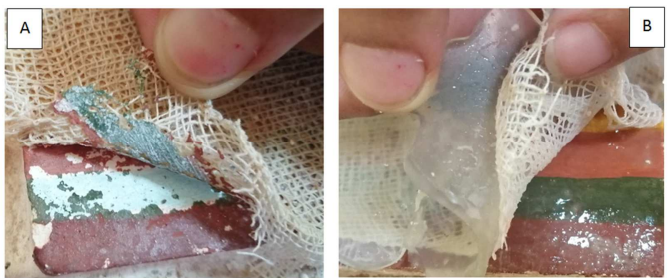

Figure 7. (A) the replica by traditional methods (warm water) to removal gauze, (B) the bio- restoration by broth media agar gel containing the Pseudomonas stutzeri.

Table 1. Effective on the application period on aged replica.

\begin{tabular}{llllll}
\hline Time (min) & $\mathbf{3 0}$ & $\mathbf{6 0}$ & $\mathbf{9 0}$ & $\mathbf{1 2 0}$ & $\mathbf{1 8 0}$ \\
\hline cotton & $+/-$ & $+/-$ & ++ & +++ & +++ \\
Agar & $+/-$ & + & ++ & +++ & ++++ \\
\hline
\end{tabular}

Codes: +/- (very low), + (low), ++ (middle), +++ (high), ++++ (very high).

\subsection{Application of in Situ Bio-restoration Process}

The in situ bio-restoration process included the following steps:

a. Mechanical cleaning by brushes and wet cotton was applied befor the bio-cleaning process to remove dusts and dirt from the surface.

b. Pseudomonas stutzeri viable cells inculated in brothanimal glue agar media were applied over the mural paintings surface by bruch technique layer by layer $(0.5$ cm high).

c. The gel layers were covered by poly ethylen to save the flexibility of agar media and left for 3 hours.

d. Portable heating device was used during application to increase the temprature inside house from 28 to $35^{\circ} \mathrm{C}$ as it was the perfect growth temprature (see 3.2).

e. After the application period, the poly ethylen was removed.

f. Final step was removing the gel agar and the medical gauze easly without causing damage for the pigments.

g. Nano silver particales (30nm) made by (EGNC- Egypt) were applied over the mural paintings surface by spray technique to sterilise the murals.

h. Fragments of mural painting pigments were taked for the characterization process.

i. Pre-consolidation process by Bolariod B72 (5\%) was applied over mural painting pigments before conservation process.
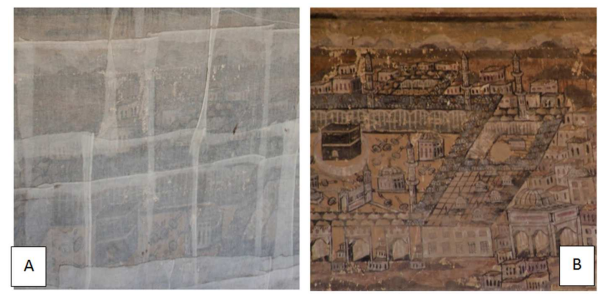

Figure 8. The mural paintings before (A) and after (B) bio-cleanings.

\subsection{Mural Paintings Structure}

Small fragments were taken from the murals paintings from both pigments and ground layers after removing gauze for examination and characterization.

\subsubsection{Ground Layer}

The XRD analysis showed that the ground layer consists of about $56 \%$ Gypsum $\left(\mathrm{CaSO}_{4} \cdot 2 \mathrm{H}_{2} \mathrm{O}\right), 38 \%$ Calcite $\left(\mathrm{CaCO}_{3}\right)$, and traces from Quartz $\left(\mathrm{SiO}_{2}\right)$ (about 6\%) as shown in Figure 9.

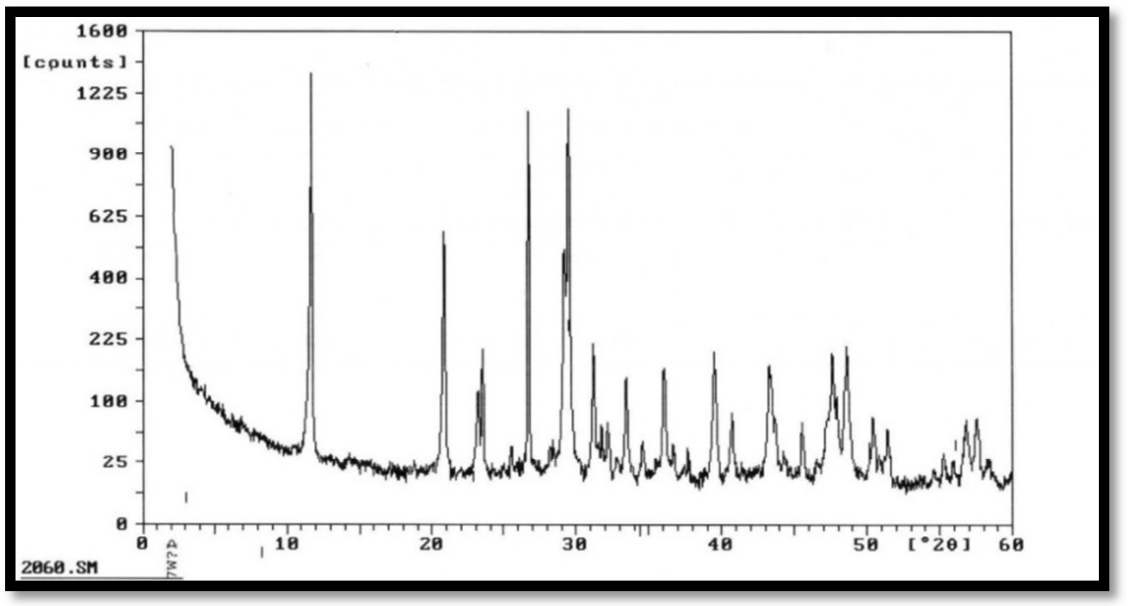

Figure 9. XRD spectrum of the ground layer. 
The SEM- EDX analysis showed that the ground layer consists of two-layers of mortar: a white sheet layer (A) is consist of Gypsum and Calcite with traces of Quartz and Halite, and the layer (B) contains Calcite, Quartz, and Gypsum, while as shown in Figures 10 and 11.

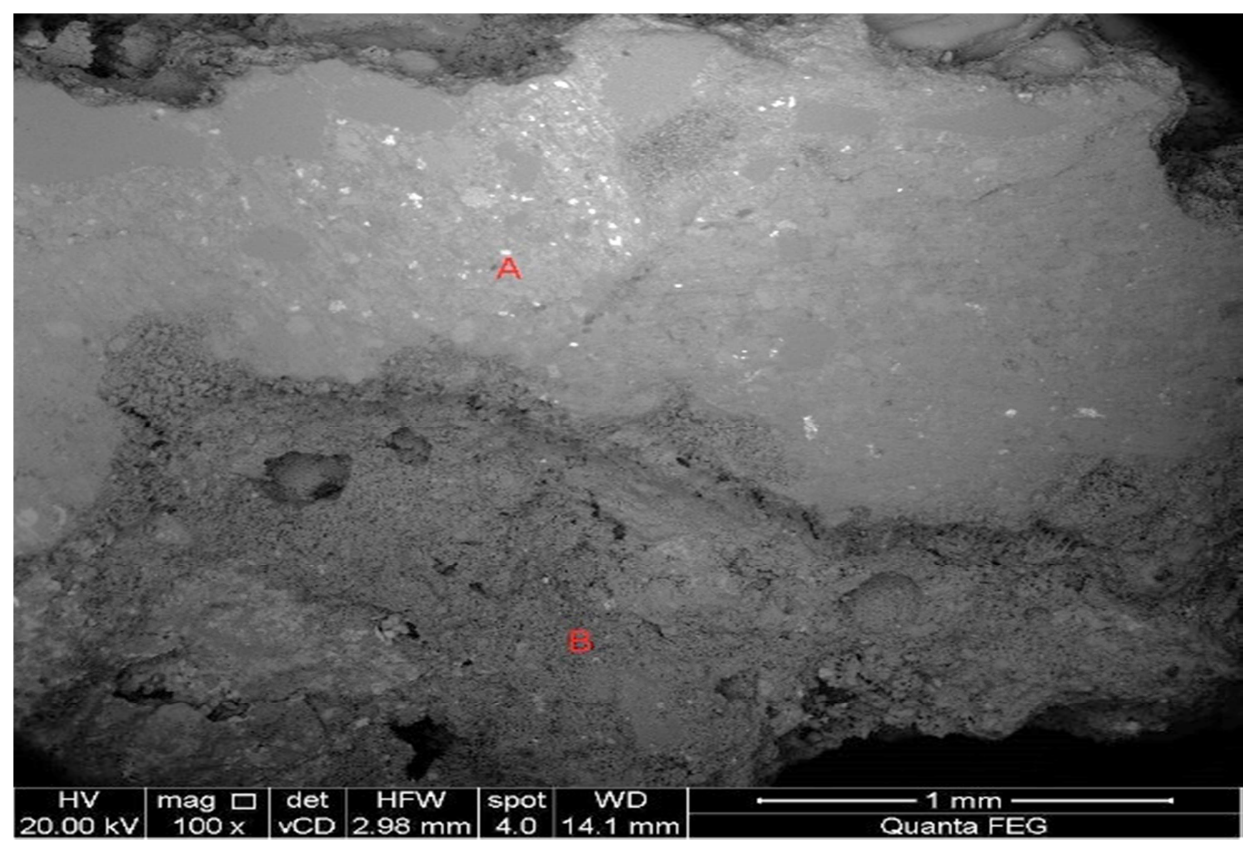

Figure 10. The ground layer of the mural paintings 100x. (A) is the white sheet layer, (B) is the mortar layer.
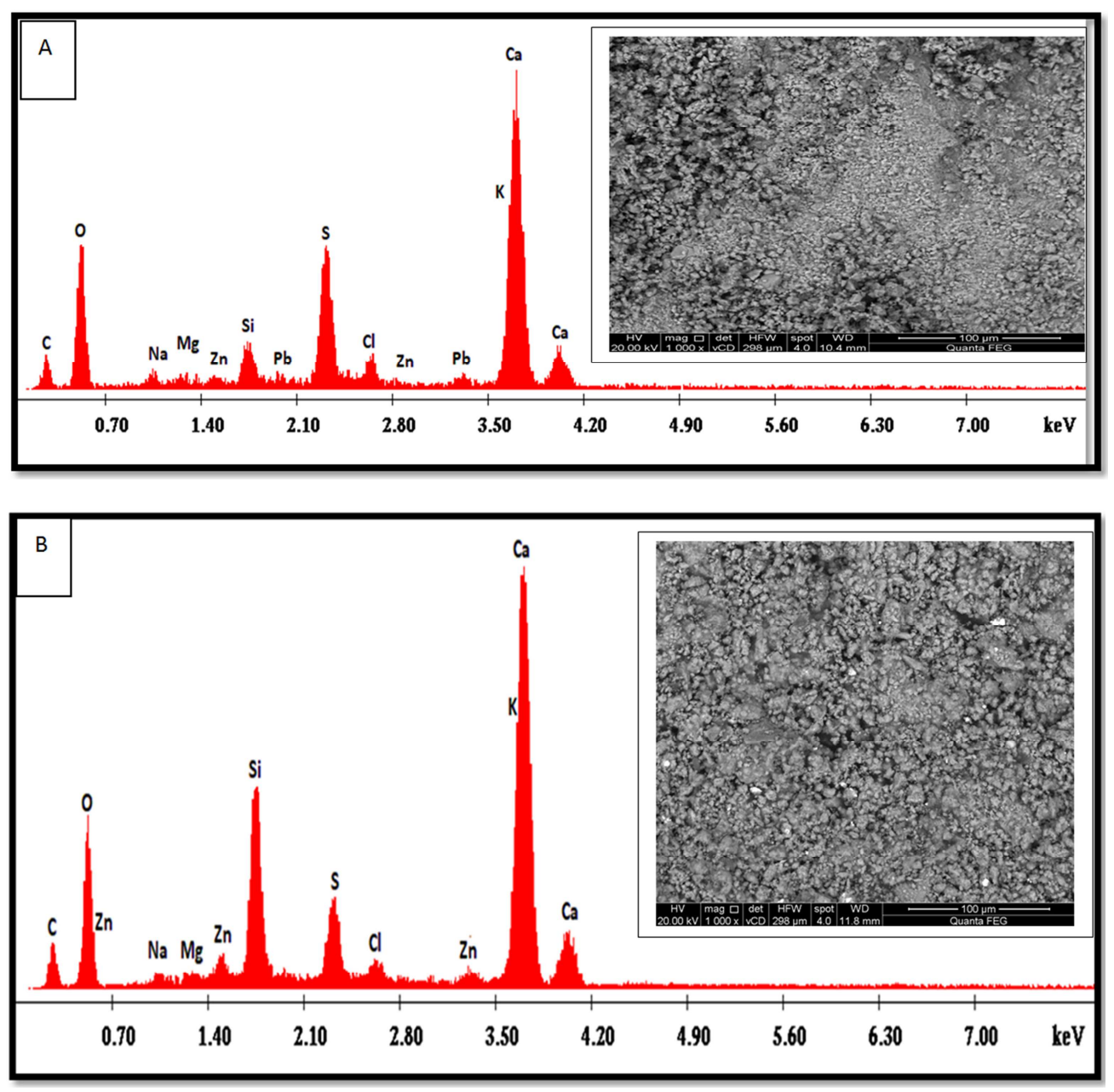

Figure 11. the EDX spectrum (A) the white sheet layer, $(B)$ the mortar layer. 


\subsubsection{Painted Layer}

The SEM-EDX analysis showed that that the main component of the black pigment is Cerussite $\left(\mathrm{PbCO}_{3}\right)$. The red pigment is a mix of Cinnabar $(\mathrm{HgS})$ and Minium $\left(\mathrm{PbO}_{4}\right)$. The Yellow pigment is Ochre $\mathrm{FeO}(\mathrm{OH}) . \mathrm{nH}_{2} \mathrm{O}$ mixed with Zinc Oxide $(\mathrm{ZnO})$ and the white pigment is a mix of Cerussite $\left(\mathrm{PbCO}_{3}\right)$ and $\mathrm{Zinc}$ oxide $(\mathrm{ZnO})$, as shown in Figures (12 to15).

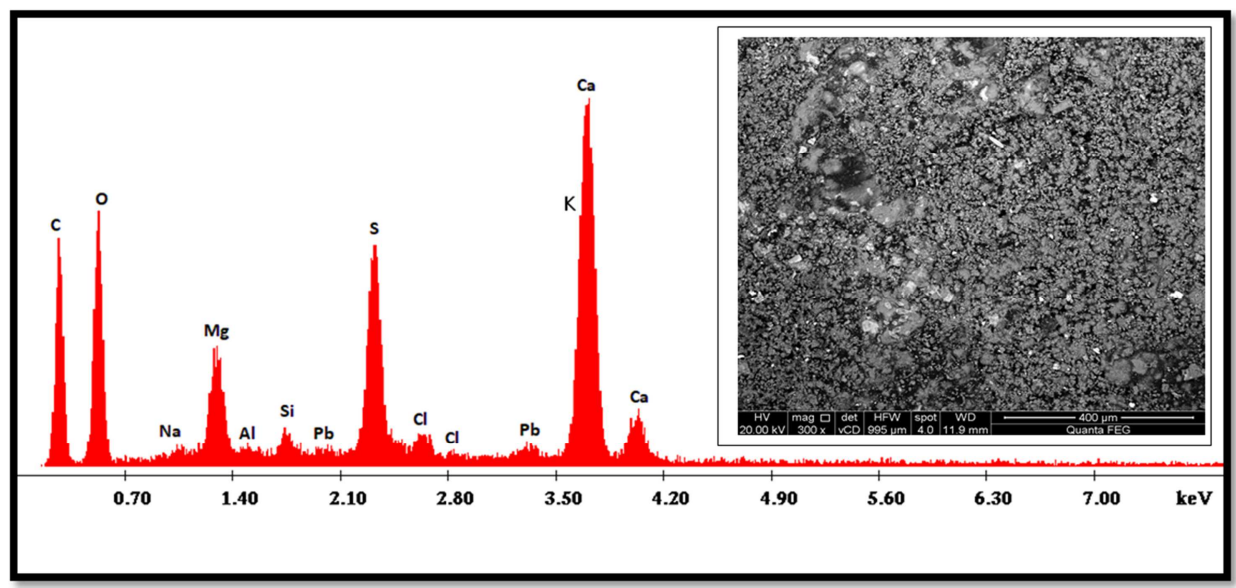

Figure 12. The spectrum of EDX analysis of the black pigment.

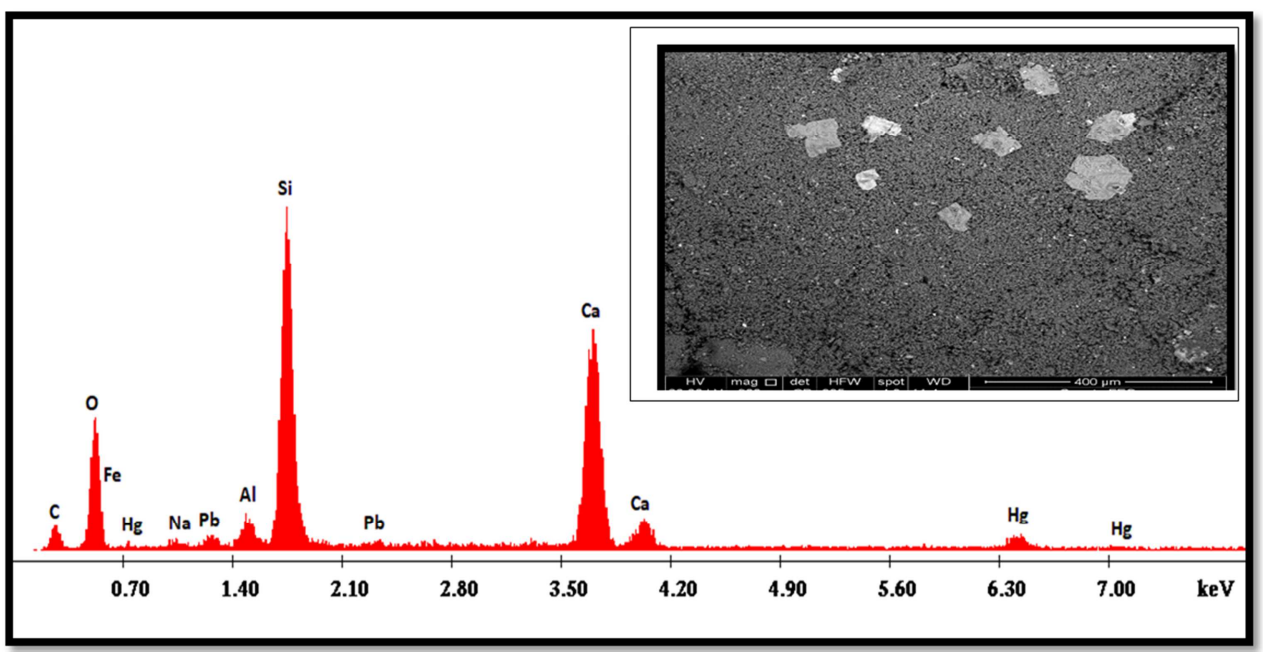

Figure 13. The spectrum of EDX analysis of the red pigment.

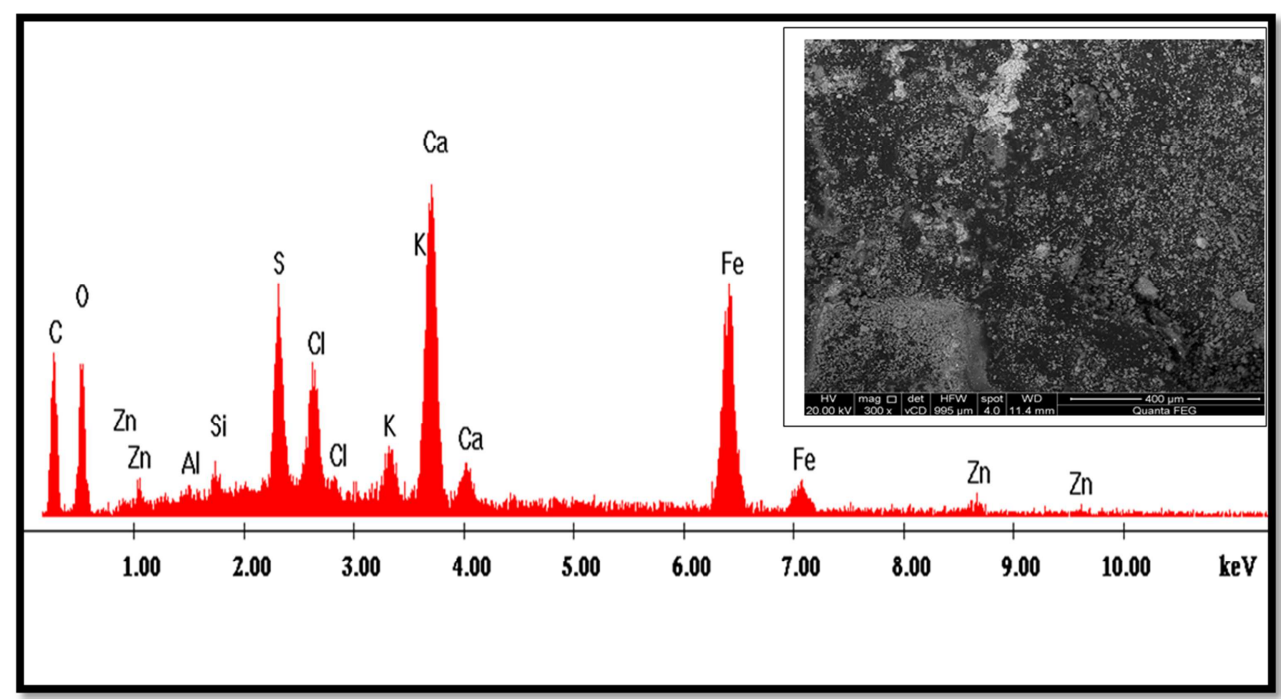

Figure 14. The spectrum of EDX analysis of the yellow pigment. 


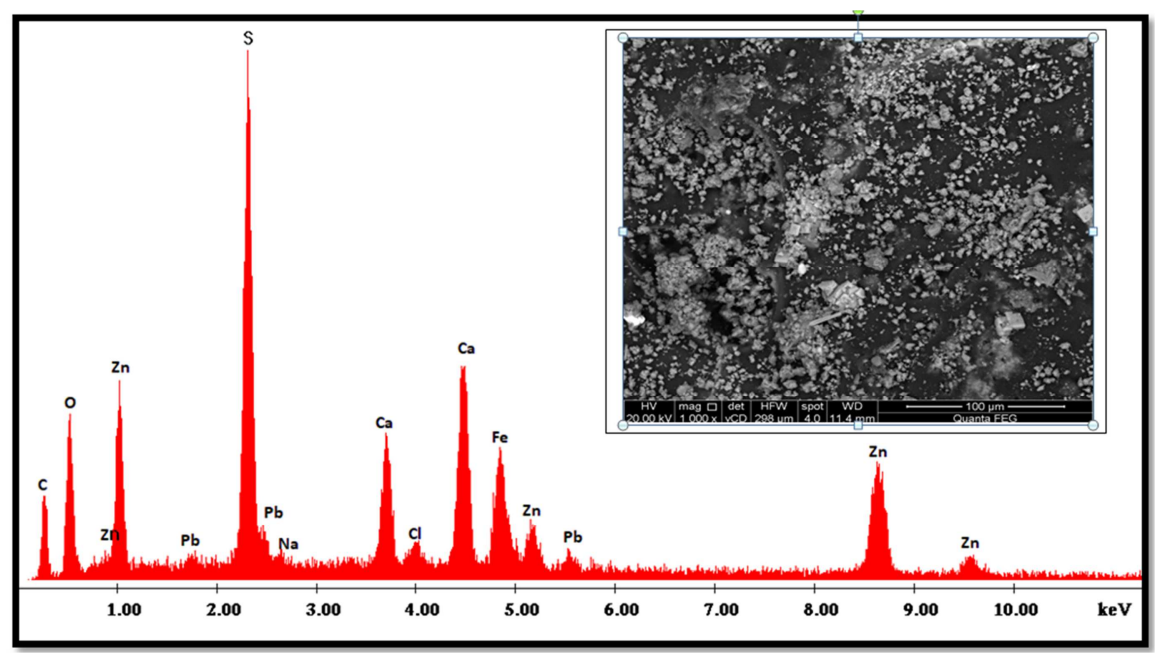

Figure 15. The spectrum of EDX analysis of the white pigment.

\subsubsection{Binding Media}

The FTIR analysis showed that none of the Functional group in the spectrum match the main groups of the binding media of the oils that usual used in this period, which mean that the pigments were mixed with water and organic media (Figure 16).

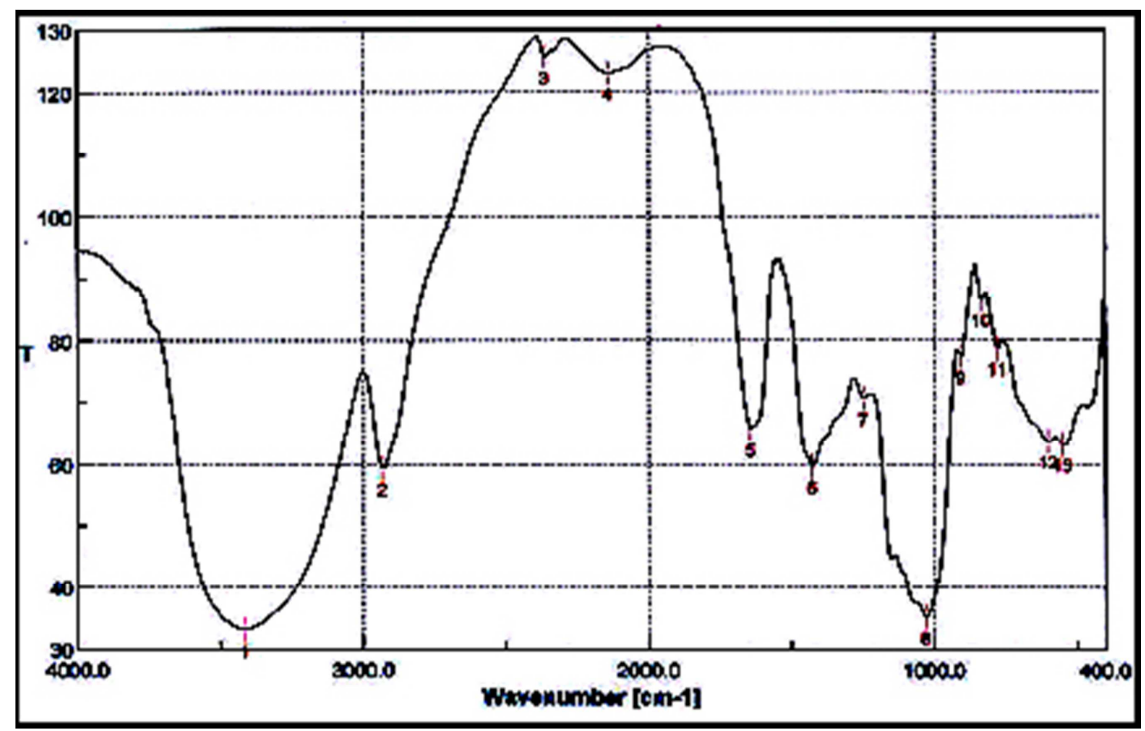

Figure 16. The FTIR spectrum of the binding medium of mural paintings in Ali katkhoda house.

\section{Discussion}

Animal glue was used for mural paintings and in conservation process as binders for pigments (Tempera animal glue), or as adhesives. [19].

Several researches have been carried out on the chemical composition of animal glue present on the mural paintings and monuments addition to the exigency of classifying it prior to degradation [20-22].

During aging, animal glue on mural paintings deteriorates, which led to create castration, tensions, crumpling, and discoloration. Therefore the removal of the deteriorated glue during restoration without effect on the pigments of mural paintings became a challenge. [23-25]

Several studies have been discussing the efficiency of a bio-conservation process in archaeological field for removing back crust, degrading organic matter, or consolidating stone and mural paintings [8, 15, 26-27]. However, the treatment duration can be changed from a few hours (Roig et al., 2011a, b), to many days, and even, to one month [28, 29].

The bio-cleaning by $P$. stutzeri used to remove organic matters such as animal glue from the protected mural paintings, bacteria applied for different times $(2,3$, and 6 hours) GC-MS and PY/GC-MS approved that animal glue and casein removed (85\% and $80 \%$, respectively). [9].

Results in this study showed that the growth of P. stutzeri in temperature less than $20^{\circ} \mathrm{C}$ has no effect and the optimum temperatures for the bacterial growth was between (30 and $35^{\circ} \mathrm{C}$ ). The growth media used in laboratory studies were two different media broth media and broth- animal glue media. The broth animal glue media was high effective for removing 
animal glue layer.

Additionally, the basis of our results we used two different delivery system cotton and agar. According to the delivery system and the type of application we would suggest to use agar delivery system beyond 180 minutes to permit $P$. stutzeri to perform most effectively.

In situ, we consider starting with mechanical cleaning to remove dust before using bio-cleaning process. The bio-cleaning process has several advantages; it is a non-destructive technique, used to remove specific substances or altered compounds from the painting, risk free, and has a good performance rate $[6,11]$. The application started by applying broth agar media inoculated with $P$. stutzeri all over the mural painting surface with a height of $0.5 \mathrm{~cm}$ for 3hour then removing the gel media easily.

Nano silver particles $(30 \mathrm{~nm})$ were applied by spray technique after removing of medical gauze and animal glue for sterilizing the mural painting against any microorganisms due to using Ag Np. as antimicrobial in several studies. [17, 27, 28].

After the bio-cleaning presses, the mural paintings have been characterized, the observation by SEM showed that the ground layer consisted of two different layers one of them is the white sheet layer. The internal layer composed of Calcite, Quartz, and Gypsum as a usual structure (Mora, 1974), while the white sheet layer was a mix of Gypsum and Calcite. The EDX analysis of the pigments showed that the black pigment is Cerussite $\left(\mathrm{PbCO}_{3}\right)$. The red pigment is a mix of Cinnabar $(\mathrm{HgS})$ and Minium $\left(\mathrm{PbO}_{4}\right)$, the Yellow pigment is Ochre $\mathrm{FeO}(\mathrm{OH}) . \mathrm{nH}_{2} \mathrm{O}$ mixed with $\mathrm{Zinc}$ Oxide $(\mathrm{ZnO})$ and the white pigment is a mix of Cerussite $\left(\mathrm{PbCO}_{3}\right)$ and $\mathrm{Zinc}$ oxide $(\mathrm{ZnO})$. All pigments might be applied as a tempera water colours due to the absence of binding media as the FTIR indicated.

\section{Conclusion}

A successful Bio-cleaning process by $P$. stutzeri was used to remove polymerized animal glue that was used previously as an adhesive over mural painting surface. Broth animal glue media was mixed with agar that used as a delivery system to keep a fine smooth gel surface above the mural surface. A various application periods were applied over replica, the best condition for application was 180 minutes at $35^{\circ} \mathrm{C}$ and $\mathrm{pH}=7.5$ was achieved. In suti the viable cells of $P$. stutzeri was inoculated in the broth media gel agar over the mural paintings layer by layer and covered with poly ethylene, after application period the gel layer was easily removed without any harmful of the mural surface. The cost of the bio-cleaning process viable bacterial cells was lower than the other conventional methods such as enzymes. Furthermore Bio-restoration was highly efficient, safe, non-invasive, risk-free and easy to apply. The mural paintings in Ali katkhoda were unique, the analysis showed that it applied by water colours over white sheet, the pigments were Cinnabar, Cerussite, Zinc oxide, and Ochre as usually used in this period in Egypt.

\section{Acknowledgements}

The author is grateful to $\mathrm{Mr}$ Filib $\mathrm{D}$. Thomas, Microbiologist Researcher, AUC, Egypt, Mr Ahmed F. Soliuman, (a.f.souliman@gmail.com), conservator in Ministry of Antiques, Egypt.

\section{References}

[1] Zaki, A. (1987) Encyclopedia of the city of Cairo in a thousand years. El Anglo publication, P. 49.

[2] Gomoiua, I., Mohanua, D., Radvanb, R., Dumbraviciana, M., Neagud SE, Cojocc LR, Enachec MI, Chelmusb A, Mohanud I.(2017) Environmental Impact on Biopigmentation of Mural Painting, Acta Physica Polonica, doi: 10.12693/APhysPolA.131.48.

[3] Abdel-Haliem, M. E. F., Sakra, A., Ali, M. F., Ghalya, M. F., Sohlenkamp, C. (2013) Characterization of Streptomyces isolates causing color changes of mural paintings in ancient Egyptian tombs. Microbiol. Res. 168: 428-437.

[4] Elhagrassy, A. F. (2018a) Isolation and characterization of actinomycetes from Mural paintings of Snu- Sert-Ankh tomb, their antimicrobial activity, and their biodeterioration Microbiological Research, 216: 47-55.

[5] Veneranda, M., Taboada, N. P., Fdez-Ortiz, de Vallejuelo, S., Maguregui, M., Marcaida, I., Castro, K., Madariaga, J. M., Osanna, M. (2017) Biodeterioration of Pompeian mural paintings: fungal colonization favoured by the presence of volcanic material residues. Environmental Science and Pollution Research, 24: 9599-1969.

[6] Elhagrassy, A. F. (2015) Bio cleaning Black Crust of culture heritage stone surface in Mohammed Ali Palace (Manial Palace) by using of Sulfate reducing Bacteria Desulfovibrio vulgaris. International Journal of New Technologies in Science and Engineering, 2: 12-19.

[7] Helmi, F. M., Elmitwalli, H. R., Rizk, M. A., Elhagrassy, A. F. (2011) Antibiotic extraction as a resent biocontrol method for Aspergillus niger and Aspergillus flavus fungi in Ancient Egyptian mural paintings, Mediterranean Archaeology and Archaeometry, 11: 1-7.

[8] Helmi, F. M., Elmitwalli, H. R., Elnagdy, S. M., ElHagrassy, A. F. (2016) Calcium carbonate precipitation induced by ureolytic bacteria Bacillus licheniformis, Ecological Engineering 90: 367-371.

[9] Lustrato, G., Alfano, G., Andreotti, A., Colombini, M. P., Ranalli. G. (2012.) Fast biocleaning of mediaeval frescoes using viable bacterial cells. International Biodeterioration \& Biodegradation, 69: 51-61.

[10] Roig, P. B. and Ranalli, G. (2014) The safety of biocleaning technologies for cultural heritage. Frontiers in Microbiology. doi: 10.3389/fmicb.2014.00155.

[11] Elhagrassy, A. F. and Hakeem, A. (2018b) Comparative Study of Biological Cleaning and Laser Techniques for Conservation of Weathered Stone in Failaka Island, Kuwait. Scientific Culture 4: 43-50. doi: 10.5281/zenodo.121456.

[12] Antonioli, P., Zapparoli, G., Abbruscato, P., Sorlini, C., Ranalli, G., Righetti, P. G. (2005) Art-loving bugs: the resurrection of Spinello Aretino from Pisa" cemetery. Proteomics, 5: 2453-2459. 
[13] Roig, B. P., Estellés, R. M., Regidor-Ros, J. L., Roig-Picazo, P, Ranalli, G. (2012) New frontiers in the microbial bio-cleaning of artworks. Picturer Restorer, 41: 37-41.

[14] Ranalli, G., Alfano, G., Belli, C., Lustrato, G., Colombini, M. P., Bonaduce, I., Zanardini, E., Abbruscato, P., Cappitelli, F., Sorlini, C. (2005) Biotechnology applied to cultural heritage: biorestoration of frescoes using viable bacterial cells and enzymes. J Appl Microbiol, 98: 73-83.

[15] Sorlini, C., Cappitelli, F. (2008) The application of viable bacteria for the biocleaning of Cultural Heritage surfaces. Coalition, 15: 18-20.

[16] Polo, A., Cappitelli, F., Brusetti, L., Principi, P., Villa, F., Giacomucci, L., Ranalli, G., Sorlini, C.(2010) Feasibility of removing surface deposits on stone using biological and chemical remediation methods. Environ Microbiol, 60: 1-14.

[17] Galdiero, S., Falanga, A., Vitiello, M., Cantisani, M., Marra, V., Galdiero, M. (2011) Silver Nanoparticles as Potential Antiviral Agents. Molecules, 16: 8894-8918.

[18] Elhagrassy, A. F., Sameh, H. I., (2019) Novel Ag@ZnO core shell for Sterilization Mural paintings of King Tutankhamon Tomb (KV62), Velly of the King, Luxor, Egypt. (Under publication).

[19] Mora, P. 1974. Causes of Deterioration of Mural paintings, International center for the study of the preservation and restoration of cultural property, Rome.

[20] Harrison, S. M, Kaml, I., Prokoratova, V., Mazanek, M., Kenndler, E. (2005) Animal glues in mixtures of natural binding media used in artistic and historic objects: identification by capillary zone electrophoresis. Anal Bioanal Chem, 382: 1520-1526.

[21] Sarmiento, A., Pérez-Alonso, M., Olivares, M., Castro, K., Martínez-Arkarazo, I., Fernández, L. A., Madariaga, J. M. (2011) Classification and identification of organic binding media in artworks by means of Fouriertrans form infrared spectroscopy and principal component analysis. Anal Bioanal Chem, 399: 3601-3611.

[22] Wei, S., Schreiner, M., Rosenberg, E., Guo, H., Ma, Q. (2011) Identification of the binding media in Tang Dynasty Chinese wall paintings by using Py-GC/MS and GC/MS techniques. Int J Conserv Sci, 2: 77-88.
[23] Jeszeová1, L., Bauerová-Hlinková, V., Baráth, P., Puškárová, A., Bučková, M., Kraková, L., Pangallo, D. (2018) Biochemical and proteomic characterization of the extracellular enzymatic preparate of Exiguobacterium undae, suitable for efficient animal glue removal, Applied Microbiology and Biotechnology, 102: 6525-6536.

[24] Roig, B. P., Regidor Ros, J. L., Montes Estellés, R. (2011a) Biolimpieza de pintura mural con bacterias. In: Proceeding of the XVIII Congreso Internacional Conservacióny Restauración de Bienes Culturales, Granada, 517-519.

[25] Roig, B. P., Regidor Ros, J. L., Soriano Sancho, P., Doménech Carbó, M. T., Montes Estellés, R.. (2011b) Ensayos de biolimpieza con bacterias en pinturas murales. Arché 4-5. Editorial de la Universidad Politécnica de Valencia, Valencia, $115-122$.

[26] Tiano, P., Cantisani, E., Sutherland, I., Paget, J. M., (2006) Bioremediated reinforcement of weathered calcareous stones. Journal of Cultural Heritage 7: 49-55.

[27] Alfano, G., Lustrato, G., Belli, C., Zanardini, E., Cappitelli, F., Mello, E., Sorlini, C., Ranalli, G., (2011) The bioremoval of nitrate and sulfate alterations on artistic stonework: the case-study of Matera Cathedral after six years from the treatment. International Biodeterioration and Biodegradation 65: 1004-1011.

[28] Webster, A., May, E., (2006) Bioremediation of weathered-building stone surface. Trends in Biotechnology 24: 255-260.

[29] Giorgi, R., Baglioni, M., Berti, D., Baglioni, P., (2010) New methodologies for the conservation of cultural heritage: micellar solutions, microemulsions, and hydroxide nanoparticles. Accounts of Chemical Research, 43: 695-704.

[30] Sajjad, S., and Nasseri, A. (2011) Synthesis and stabilization of Ag nanoparticles on a polyamide surface and its antibacterial effects. Int. Nano. Lett. 1: 22.

[31] Franci, G., Falanga, A., Galdiero, S., Palomba, L., Rai, M., Morelli, G., Galdiero, M. (2015) Silver Nanoparticles as Potential Antibacterial Agents, Molecules, 20: 8856-8874. 